\title{
Contribuição para o aprimoramento de projeto, construção e operação de reatores UASB aplicados ao tratamento de esgoto sanitário - Parte 6: Qualidade do efluente
}

\section{Contribution for improving the design, construction and operation of UASB reactors treating sewage - Part 6: Effluent quality}

Data de entrada: 01/08/2018

Data de aprovação: $17 / 09 / 2018$

Paulo Gustavo Sertório de Almeida / Thiago Bressani Ribeiro / Bruno Sidnei da Silva / Lariza dos Santos Azevedo / Carlos Augusto de Lemos Chernicharo (*)

DOI: $10.4322 /$ dae.2018.043

\section{Resumo}

A qualidade do efluente de estações de tratamento de esgoto que possuem reatores UASB como parte integrante do tratamento biológico do esgoto depende essencialmente de aspectos de projeto, construção e operação que permitam o necessário gerenciamento do lodo anaeróbio, bem como a adequada operação da etapa de pós-tratamento por processos aeróbios. A presente Nota Técnica essencialmente apresenta um conteúdo complementar à Parte 3 desta Coletânea de Notas Técnicas, no sentido de discutir a origem de problemas e os possíveis aprimoramentos de projeto, construção e operação para reatores UASB seguidos de etapa de pós-tratamento por filtros biológicos percoladores. São discutidos: i) aspectos de projeto e operação que influenciam a perda de sólidos com o efluente anaeróbio, incluindo a influência do envio do lodo aeróbio a reatores UASB; ii) aspectos associados aos requisitos de lançamento em corpos receptores; e iii) deficiências em unidades de pós-tratamento por filtros biológicos percoladores. Especial atenção é dada: i) aos aspectos de sistematização operacional para o controle do lodo no sentido de evitar a perda de sólidos com o efluente; ii) à remoção de matéria orgânica, visando o atendimento a padrões de lançamento; e iii) a fatores que podem influenciar o desempenho de filtros biológicos percoladores pós-reatores UASB. Palavras-chave: Melhoria da qualidade do efluente; sistematização operacional; pós-tratamento.

\section{Abstract}

The effluent quality of sewage treatment plants comprised byUASB reactors essentially depends on design, construction and operational aspects that allow the necessarymanagement of the anaerobicsludge, as well as the appropriate

\footnotetext{
Paulo Gustavo Sertório de Almeida - Engenheiro Civil pela UFJF. Mestre e Doutor em Saneamento, Meio Ambiente e Recursos Hídricos pela UFMG. Membro do INCT ETEs Sustentáveis.

Thiago Bressani Ribeiro - Engenheiro Ambiental pela Universidade FUMEC. Mestre em Saneamento, Meio Ambiente e Recursos Hídricos pela UFMG. Doutorando em Saneamento pelas Universidades de Ghent (Bélgica) e UFMG. Membro do INCT ETEs Sustentáveis.

Bruno Sidnei da Silva - Engenheiro Ambiental pela UFSC. Mestre em Engenharia Hidráulica e Ambiental pela EPUSP. Engenheiro da Companhia de Saneamento Básico do Estado de São Paulo (Sabesp).

Lariza dos Santos Azevedo - Engenheira Ambiental e Sanitarista pela UFJF. Mestre em Saneamento, Meio Ambiente e Recursos Hídricos pela UFMG. Membro do INCT ETEs Sustentáveis.

Carlos Augusto de Lemos Chernicharo - Engenheiro Civil pela UFMG. Doutor em Engenharia Ambiental pela Universidade de Newcastle upon Tyne - UK. Professor titular do Departamento de Engenharia Sanitária e Ambiental da UFMG. Coordenador INCT ETEs Sustentáveis.

"Endereço para correspondência: Avenida Antônio Carlos 6.627 - Universidade Federal de Minas Gerais - Escola de Engenharia - Departamento de Engenharia Sanitária e Ambiental - Bloco 1. Belo Horizonte, MG. CEP: 31270-901. e-mail: calemosadesa.ufmg.br
} 
operation of the aerobic post-treatmentstep. This Technical Note is a complementary material to Part 3 of these Technical Notes series aiming to present the problems and their respective origins, as well as the possible improvements of design, construction and operation ofUASB reactors followed by trickling filters (TF). The discussed topics are:i) design and operation aspects that affect solid washouts in UASB effluent, including the influence of aerobic sludge return, ii) the compliance to discharge standards, and iii) deficiencies related to the post-treatment step. Special attention is given to: i) operational control of the sludge in order to avoid solids washouts; ii) organic matter seeking to comply with discharge standards; and iii) factors influencing the performance of trickling filters following UASB reactors. Keywords: Effluent quality improvement; operational control; post-treatment.

\section{INTRODUÇÃO}

Conforme discutido no conjunto de Notas Técnicas (NTs) que compõem a presente Coletânea, a qualidade do efluente final de reatores UASB é influenciada por aspectos de projeto, construção e operação, os quais podem afetar também a etapa de pós-tratamento. Neste caso, o controle da perda de sólidos com o efluente anaeróbio é um aspecto crucial para o desempenho global do sistema. Na presente NT, maior destaque é dado aos filtros biológicos percoladores (FBP), por se tratarem da alternativa de pós-tratamento mais empregada nas ETEs brasileiras que utilizam reatores anaeróbios como primeiro estágio do tratamento (CHERNICHARO et al. 2018a). Todavia, devido à importância do envio de lodo aeróbio proveniente da etapa de pós-tratamento para adensamento e digestão nos reatores UASB, também os sistemas de lodo ativado são contextualizados nessa NT.

A sistematização operacional de reatores UASB, em termos do controle da perda de sólidos com o efluente, depende em grande parte de definições de projeto, a exemplo da previsão e detalhamento de adequados sistemas de descarte de lodo e de escuma. Da mesma forma, a compatibilização da produção efetiva de lodo na ETE com o dimensionamento das unidades de gerenciamento da fase sólida é importante condicionante para o sucesso operacional de sistemas com reatores UASB seguidos de etapa de pós-tratamento. Consecutivamente, a elaboração e a implementação efetiva de protocolos de descarte de lodo e de escuma são etapas da maior relevância para a operação bem sucedida das unidades que compõem a ETE.

Quanto à influência da operação da etapa de pós-tratamento na qualidade do efluente do reator UASB e nas unidades de gerenciamento da fase sólida, em que pesem as vantagens associadas ao envio do lodo aeróbio para adensamento e digestão em reatores UASB, esta estratégia tem sido apontada como uma das causas da perda de sólidos com o efluente. A presença excessiva de sólidos no efluente anaeróbio tende a promover maior resistência à transferência de massa em sistemas com biofilme, bem como redução no tempo de residência da biomassa aeróbia em sistemas de lodo ativado. Em casos extremos, a colmatação de leitos de pedra em FBPs pela elevação da carga de sólidos encaminhada com o efluente anaeróbio tem sido observada. No caso do pós-tratamento por lodo ativado, a perda excessiva de sólidos com o efluente dos reatores UASB, associada a uma baixa capacidade de remoção do lodo aeróbio excedente, refletem nos requisitos de oxigênio no tanque de aeração e no consumo de energia.

Embora o controle da perda de sólidos com o efluente anaeróbio a partir do gerenciamento adequado do lodo seja um importante fator para a qualidade do efluente de reatores UASB, outros aspectos são também considerados relevantes para o atendimento a padrões de qualidade. So- 
brecargas hidráulicas ou picos de vazão em virtude do aporte de águas pluviais ou falhas na operação de elevatórias são exemplos de fatores intervenientes que devem ser considerados. Adicionalmente, a remoção de nitrogênio, fósforo e surfactantes não é esperada em reatores UASB. Neste caso, a etapa de pós-tratamento pode ser necessária não somente para o polimento do efluente em termos de concentrações de matéria orgânica. Contudo, deficiências e falhas operacionais em relação às unidades de pós-tratamento podem comprometer sobremaneira o desempenho global do sistema.

Considerando os aspectos anteriormente reportados, a presente NT discute a origem de problemas e os possíveis aprimoramentos associados a projeto, construção e operação de reatores UASB, incluindo a etapa de pós-tratamento por FBPs. Uma vez que vários aspectos para aprimoramento de projeto e operação de reatores UASB foram contextualizados na Parte 3 desta Coletânea de NTs (LOBATO et al., 2018), neste documento a abordagem sobre o controle do lodo assume um caráter complementar em relação a: i) aspectos de projeto e operação que influenciam a perda de sólidos no efluente anaeróbio, considerando o envio de lodo aeróbio para reatores UASB; ii) aspectos associados ao não atendimento aos requisitos de lançamento em corpos receptores; e iii) deficiências em unidades de pós-tratamento.

\section{ORIGEM E PROBLEMAS RELACIONADOS À PERDA DE SÓLIDOS NO EFLUENTE ANAERÓBIO}

\subsection{Excesso de lodo no interior dos reatores UASB}

Conforme abordado na Parte 3 desta Coletânea de NTs (Lobato et al., 2018), a fim de se evitar a perda indesejada de sólidos junto ao efluente anaeróbio, deve-se manter a massa de lodo no interior do reator UASB limitada a um valor má- ximo, dependente da capacidade de retenção de lodo no mesmo. Concomitantemente a uma massa máxima que o reator consegue armazenar, também a concentração de lodo no ponto mais elevado do compartimento de digestão deve ser baixa (inferior a 0,5\% ST).

A título de exemplo, na Figura 1a são apresentadas as massas de lodo e as concentrações de sólidos sedimentáveis no efluente de quatro reatores UASB de mesmo volume que integram uma ETE em escala plena. Por sua vez, na Figura 1 b são apresentadas as concentrações de lodo (sólidos totais - ST) ao longo da altura do compartimento de digestão dessas mesmas quatro unidades. Nota-se que todos os reatores estão com massa de lodo acima da máxima recomendada, definida especificamente para os quatro reatores em questão como da ordem de 9.000 kgST (Figura 1a). Adicionalmente, também as concentrações de lodo no ponto de amostragem mais elevado, a 2,0 m do fundo dos reatores, estão acima de $0,5 \%$ ST (da ordem de 2,5 \% ST - Figura $1 \mathrm{~b}$ ).

Como resultado, verifica-se que todos os quatro reatores UASB apresentam elevadas concentrações de sólidos sedimentáveis no efluente (medianas variando entre 2 e $3 \mathrm{~mL}$. L-1 - Figura 1a), o que confirma que esses reatores estão com massas de lodo acima de suas capacidades de armazenamento. Cabe ressaltar que reatores UASB operados adequadamente (sem excesso de lodo) potencialmente produziriam efluentes com concentrações de sólidos sedimentáveis abaixo de $1 \mathrm{~mL} . \mathrm{L}^{-1}$.

A origem do problema de excesso de lodo encontra-se possivelmente relacionada aos seguintes aspectos: i) falta de capacidade da unidade de desaguamento para receber o lodo de descarte anaeróbio; e/ou ii) falta de protocolos sistematizados de descartes. 


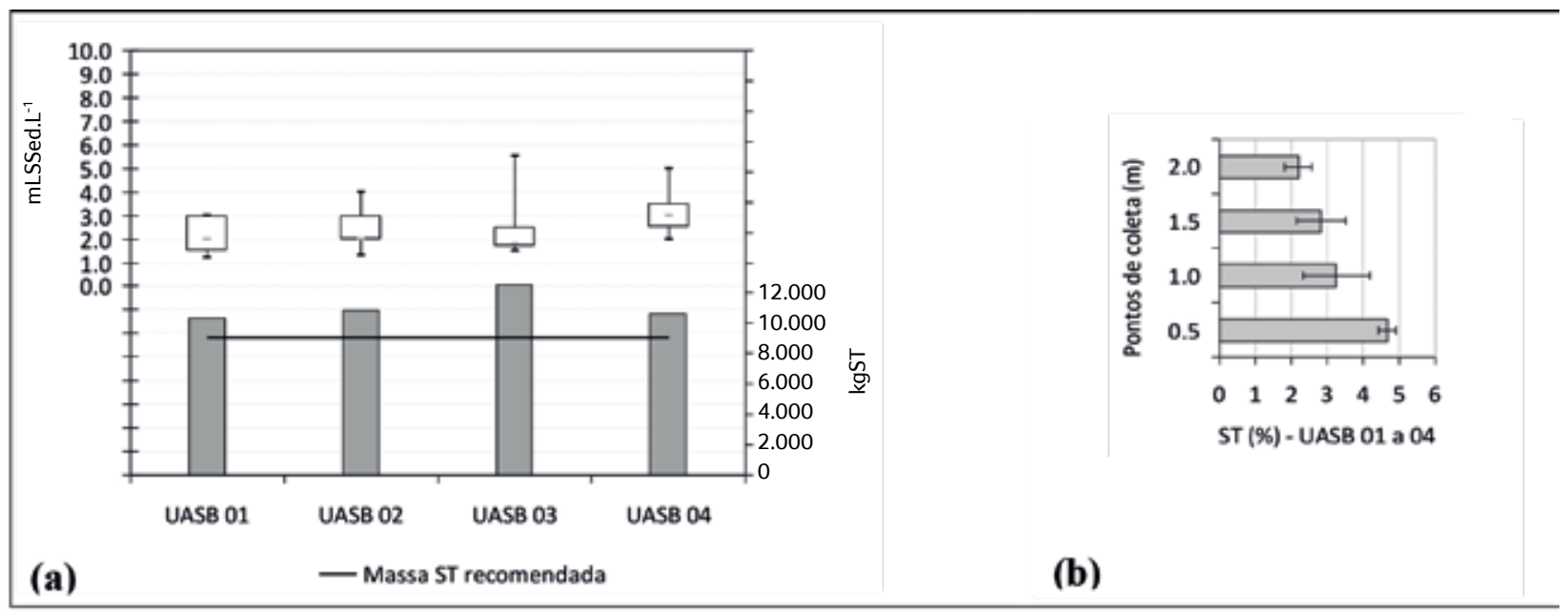

Figura 1 - a) Relação entre massa de lodo (kgST) no compartimento de digestão e concentração de sólidos sedimentáveis no efluente dos reatores UASB $\left(\mathrm{mL}_{\mathrm{L}} \mathrm{L}^{-1}\right)$; b) perfil de sólidos ao longo da altura do compartimento de digestão dos reatores UASB.

\subsection{Rotina inadequada de envio de lodo aeróbio para reatores UASB}

Conforme apresentado na Parte 3 desta Coletânea de NTs (LOBATO et al., 2018), o envio do lodo aeróbio excedente para adensamento e digestão em reatores UASB tem sido apontado como uma das causas da perda de sólidos no efluente desses reatores. Existem vários relatos de operadores de ETEs que associam essa perda de sólidos às características do lodo aeróbio, que supostamente teria composição diferente do lodo anaeróbio e, portanto, tenderia a flotar e ser perdido com o efluente do reator UASB. Por outro lado, estudos criteriosos em duas ETEs em escala plena indicaram boas características de sedimentabilidade do lodo aeróbio enviado para os reatores UASB (CHERNICHARO et al., 2013; FLORIPEZ, 2015) e apontaram que a causa da perda de sólidos no efluente anaeróbio estaria mais associada à ausência de um protocolo adequado de gerenciamento de lodo na ETE, envolvendo tanto o descarte de lodo dos reatores UASB, quanto o envio de lodo aeróbio das unidades de pós-tra- tamento para adensamento e digestão nos reatores anaeróbios.

Ratifica esse entendimento o fato de que diversas ETEs apresentam sérias dificuldades no gerenciamento do lodo, sendo bastante comum a ocorrência de significativos passivos de lodo tanto nos reatores UASB como nos decantadores secundários das unidades de pós-tratamento. No caso particular dessas últimas, é comum encontrar concentrações muito elevadas de ST na etapa de decantação secundária ( 4,0 \%), muito acima das concentrações previstas em projeto (< 1,0\%). Embora tal condição pareça improvável, essa realidade tem sido observada com recorrência, muito possivelmente pela contribuição expressiva da parcela de lodo perdida no efluente anaeróbio que acaba chegando ao decantador secundário (DS), mais particularmente no caso de DS pós-FBPs. Uma indicação de que se trata de acúmulo de lodo anaeróbio nos decantadores secundários é a nítida produção de gases na superfície dessas unidades. $\mathrm{Na}$ Figura 2 é apresentado o aspecto do acúmulo excessivo de lodo anaeróbio em um DS pós-FBP. 

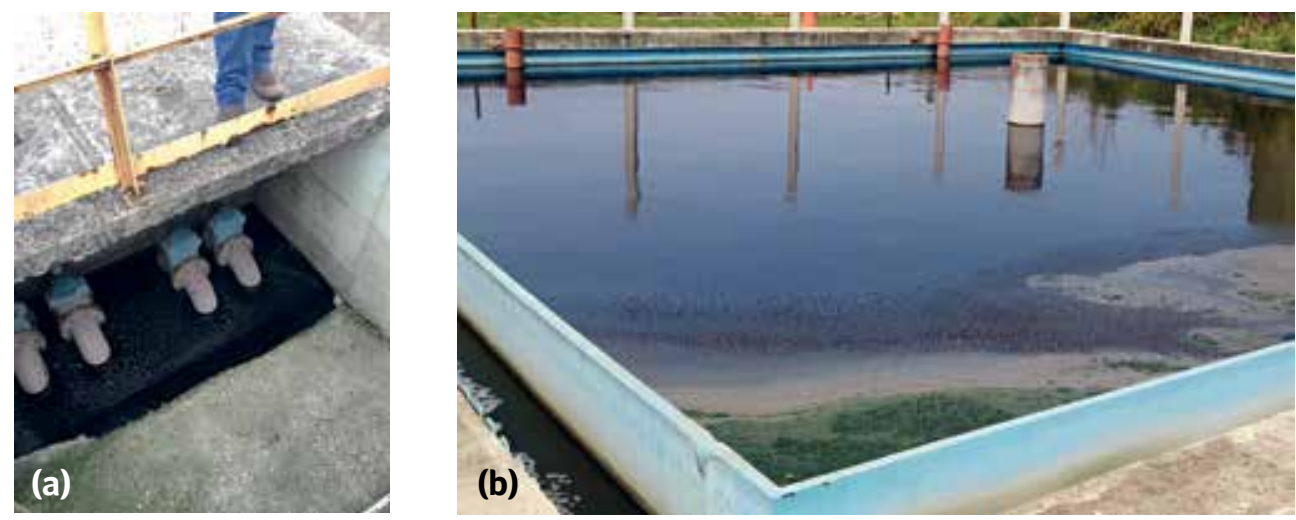

Figura 2 - a) Lodo negro e concentrado descartado de DS pós-FBP; b) Lodo flotado e bolhas de gás na superfície de DS pós-FBP.

Entre as possíveis razões para o excessivo acúmulo de lodo anaeróbio nos DS pode-se citar: i) falta de capacidade instalada das unidades de desaguamento (mecanizadas ou por leito de secagem); ii) longos períodos de manutenção das unidades mecanizadas de desaguamento e/ou limpeza de leitos de secagem, o que impossibilita o descarte de lodo excedente; e iii) dificuldades logísticas associadas ao encaminhamento do lodo para a disposição final.

Face ao exposto, com vistas a eliminar o passivo de lodo acumulado nos DS, as vazões de lodo enviadas aos reatores UASB devem ser significativamente maiores (cerca de quatro vezes mais elevadas) em comparação às vazões que seriam praticadas se o lodo nos DS tivesse a concentração prevista em projeto, inferior a 1,0 \%. Adicionalmente, estas vazões de envio de lodo são muitas vezes praticadas em bateladas tipicamente curtas (da ordem de poucas horas), muitas vezes coincidentes com momentos de vazões afluentes de esgoto mais elevadas, o que tende a ocasionar: i) incremento das velocidades ascensionais nos reatores UASB, o que, por sua vez, pode impactar na maior perda de sólidos com o efluente; e ii) redução significativa na capacidade de armazenamento de lodo nos reatores UASB, em função da sobrecarga de sólidos recebida. Portanto, caso não ocorra a remoção concomitante dos passivos de lodo nos DS e nos reatores UASB, este lodo acabará por retornar, de forma cíclica, aos FBPs, aos DS e, por fim, novamente aos reatores UASB.

Um exemplo prático que demonstra o impacto do envio de lodo aeróbio proveniente de sistema de lodo ativado para reatores UASB, em decorrência do inadequado gerenciamento de lodo nos reatores anaeróbios, é apresentado a seguir: a partir de concentrações de demanda química de oxigênio (DOO) efluentes de um reator UASB obtidas para diferentes cenários operacionais (Figura 3), observa-se que quando o lodo de fundo do reator UASB não foi removido do compartimento de digestão (condições NN e SN), o envio do lodo aeróbio para o reator UASB praticamente não exerceu influência na qualidade do efluente anaeróbio. Quando a remoção de lodo de fundo do reator UASB foi efetuada, houve incremento das concentrações efluentes de DQO, mesmo sem o envio do lodo aeróbio (condição NS). Após o envio do lodo, uma maior variabilidade das concentrações de DQO (condição SS) foi observada. Ressalta-se que as mesmas tendências para concentrações de sólidos suspensos totais (SST) foram notadas. 


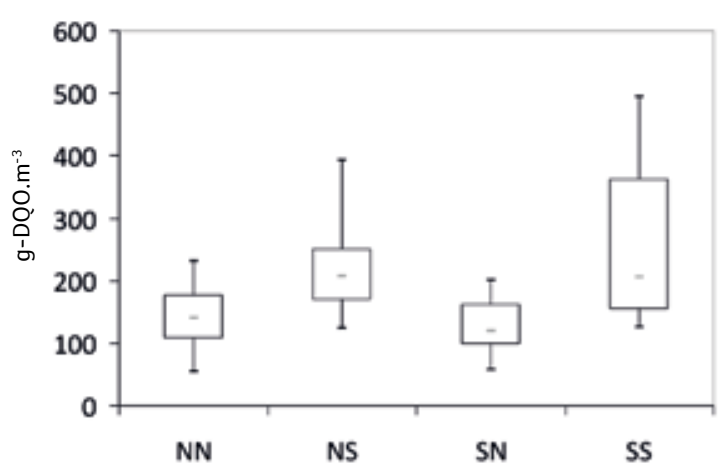

Figura 3 - Influência do envio de lodo aeróbio e descarte do lodo anaeróbio de fundo nas concentrações efluentes de DQQO e SST do reator UASB. As siglas N (não); S (sim) se referem ao envio de lodo aeróbio para o reator UASB e remoção de lodo de fundo do UASB, respectivamente.

Fonte: Adaptado de Silva (2018)

Em última análise, o estudo de caso com sistemas UASB seguido por lodo ativado mostra que o sucesso operacional do envio do lodo aeróbio depende de dois aspectos: i) compatibilidade entre critérios operacionais para o controle da idade do lodo no tanque de aeração e para o envio do lodo aeróbio; e ii) sistematização operacional para o descarte de lodo de excesso de reatores UASB visando a manutenção do lodo de maior sedimentabilidade no fundo da unidade.

\subsection{Estratégia de controle da idade do lodo aeróbio em sistema de lodo ativado}

A remoção do lodo aeróbio excedente para o controle da idade do lodo nos sistemas de lodo ativado pode ser realizada por meio de duas alternativas: i) pela remoção de fração do lodo ativado diretamente do tanque de aeração (opção conhecida como "descarte hidráulico"); ou ii) pela remoção de fração do lodo sedimentado nos decantadores secundários. As duas alternativas apresentam vantagens e desvantagens em relação ao controle da idade do lodo no tanque de aeração e encaminhamento do lodo aeróbio excedente aos reatores UASB para adensamento e digestão.
- Envio do lodo aeróbio excedente diretamente do tanque de aeração. Com o uso dessa alternativa, a concentração de descarte é a própria concentração de sólidos no tanque de aeração. Neste caso, o controle da idade do lodo torna-se mais simples, sendo uma razão entre o volume do reator (tanque de aeração) e o volume de lodo removido diariamente. Tendo em vista que o lodo aeróbio excedente é encaminhado para o reator UASB a partir do tanque de aeração, o volume de lodo encaminhado tende a ser maior (cerca do dobro), em comparação com a estratégia de envio do lodo aeróbio de excesso a partir dos decantadores secundários.

- Envio de fração do lodo sedimentado nos decantadores secundários. Neste caso, o controle da idade do lodo é efetuado a partir da concentração de sólidos em suspensão voláteis no tanque de aeração e no lodo sedimentado nos decantadores secundários (lodo de recirculação). Apesar da maior complexidade para a determinação da idade do lodo, o lodo excedente é encaminhado para os reatores UASB a partir da linha de recirculação dos decantadores secundários e, portanto, em menor volume, tendo em vista a maior concentração em termos de sólidos.

Portanto, o critério adotado para o controle da idade do lodo no tanque de aeração altera o volume de lodo aduzido aos reatores UASB para adensamento e digestão. O encaminhamento de maiores volumes de lodo aos reatores UASB pode exercer influência na qualidade do efluente anaeróbio, principalmente durante os picos de vazão afluente à ETE.

Ressalta-se, no entanto, que qualquer que seja a alternativa adotada, caso o lodo excedente aeróbio enviado para os reatores UASB seja arrastado para a superfície e perdido com o efluente do reator, isso causará um descontrole da idade do lodo ativado, pois parte do lodo considerada retirada do processo acaba voltando para o tanque de aeração. 


\subsection{Fuga de gases do interior do}

Separador Trifásico (STF) para o compartimento de decantação

Tal como caracterizado na Parte 3 desta Coletânea de NTs (LOBATO et al., 2018), a não remoção sistemática da camada de escuma que se acumula no interior do separador trifásico pode levar ao espessamento e solidificação do material acumulado. Isso acarreta em bloqueio parcial ou integral da interface de liberação dos gases formados durante a digestão anaeróbia. Dessa forma, o fluxo gasoso que ingressaria à câmara de gás do separador trifásico tende a escapar para o compartimento de decantação de reatores UASB, ocasionando o arraste de sólidos que retornariam ao compartimento de digestão, comprometendo, por consequência, a qualidade do efluente anaeróbio em termos da concentração de SST. Em sistemas que empregam unidades de pós-tratamento, a frequente sobrecarga de sólidos pode resultar em problemas de entupimentos/colmatação, especialmente em reatores de biomassa aderida (p.ex. filtros biológicos percoladores e wetlands). A utilização de separadores trifásicos equipados com dispositivo de remoção de escuma (a exemplo do mecanismo hidrostático proposto por Lobato et al. (2018)) é crucial para a mitigação da fuga de gases do interior do STF para o compartimento de decantação de reatores UASB.

\subsection{Desnivelamento de vertedores e acúmulo de escuma na superfície de decantadores}

O desnivelamento de vertedores instalados nas canaletas de saída do efluente anaeróbio é um importante fator para o acúmulo de escuma na superfície do compartimento de decantação de reatores UASB. Em princípio, tal desnivelamento tende a criar um caminho preferencial para o efluente tratado e acúmulo progressivo de escuma em zonas de estagnação hidráulica parcial (locais onde menores vazões pelos vertedores são observadas). Nestas zonas de estagnação, o escoamento do lí- quido parece não garantir a saída permanente de frações particuladas com o efluente, havendo, portanto, o acúmulo de material flotante (Figura 4).

O acúmulo de escuma na superfície dos compartimentos de decantação pode refletir em deterioração da qualidade do efluente anaeróbio pela elevação das concentrações de sólidos.

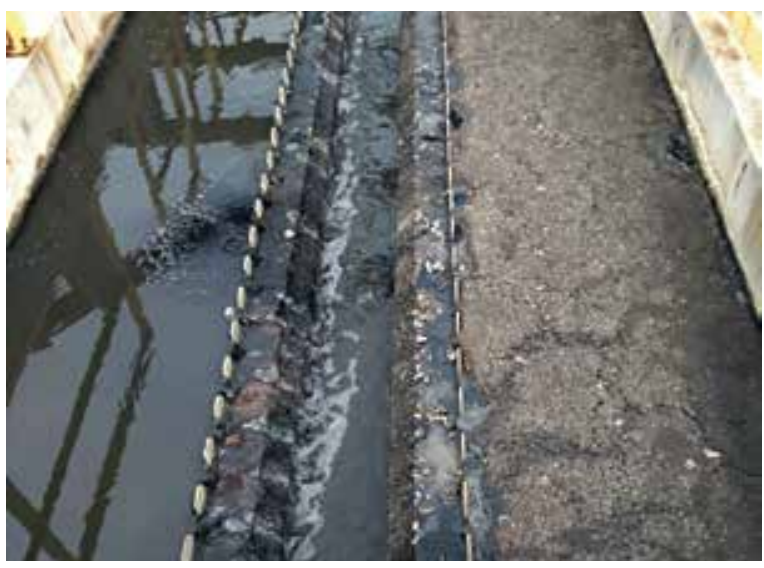

Figura 4 - Acúmulo de escuma em decorrência de vertedores desnivelados.

\subsection{Sobrecargas hidráulicas e picos excessivos de vazão}

Sobrecargas hidráulicas e picos excessivos de vazão podem provocar a expansão excessiva da manta de lodo na câmara de digestão dos reatores UASB, com a consequente sobrecarga dos compartimentos de decantação e perda excessiva de sólidos juntamente com o efluente anaeróbio. Eventos de sobrecargas hidráulicas e de picos de vazão (grande amplitude de variação entre vazões máximas e mínimas) podem estar relacionados a quatro situações principais: i) intrusão excessiva de águas pluviais; ii) vazões de bombeamento não compatíveis com as vazões médias e máximas utilizadas no projeto dos reatores anaeróbios, conforme abordado na Parte 2 desta Coletânea de NTs (BRESSANI-RIBEIRO et al., 2018); iii) contribuições advindas de localidades muito pequenas (p. ex.: cidades com populações inferiores a 2.000 hab.), 
que tendem a apresentar hidrogramas com picos de vazão dotados de grandes desvios em relação à vazão média de projeto; e iv) inadequação das condições de envio de lodo aeróbio de decantadores secundários da unidade de pós-tratamento para adensamento e digestão nos reatores UASB, conforme discutido anteriormente.

\section{POSSIVVEIS APRIMORAMENTOS RELACIONADOS À PERDA DE SÓLIDOS NO EFLUENTE ANAERÓBIO}

\subsection{Existência de pontos de amostragem de lodo nos reatores UASB}

Conforme detalhado na Parte 3 desta Coletânea de NTs (LOBATO et al., 2018), a existência de pontos de amostragem de lodo, adequadamente posicionados ao longo da altura do compartimento de digestão de reatores UASB, é essencial para que o operador tenha melhores condições de avaliar se o reator não está com excesso (passivo) de lodo em seu interior. Entende-se que a massa de lodo excedente é a diferença entre a massa de lodo atual no reator UASB (determinada a partir da implementação do perfil de sólidos no compartimento de digestão) e a massa de lodo a ser mantida no sistema (massa de lodo entre a massa mínima e máxima, conforme discutido em Lobato et al. (2018)).

De particular interesse é a amostragem sistemática de lodo no ponto mais elevado do compartimento de digestão, localizado imediatamente antes do defletor de gases. Segundo destacado por Lobato et al. (2018) no item "Definição das quantidades de lodo a serem mantidas e a serem descartadas do reator", a concentração de lodo nesse ponto mais elevado de amostragem deve ficar sempre abaixo de 0,5 \% ST.

\subsection{Sistematização de procedimentos e rotinas operacionais para o gerenciamento de lodo}

Além das recomendações para o gerenciamento do lodo produzido nos reatores UASB, descritas na Parte 3 desta Coletânea de NTs (LOBATO et al., 2018), os procedimentos e rotinas operacionais para o adequado manejo do lodo produzido nas unidades aeróbias de pós-tratamento (FBPs e lodo ativado) devem ser detalhados nos manuais ou diretrizes de operação. Dessa forma, é imprescindível que se considere no contrato do projeto a necessidade de elaboração de tais documentos, visando a sistematização do gerenciamento do lodo na ETE.

\section{(i) Gerenciamento do lodo e controle simultâneo da qualidade do efluente de reatores UASB}

Conforme ressaltado, a qualidade do efluente de reatores UASB em termos de concentrações de sólidos suspensos está estritamente associada à massa de lodo anaeróbio mantida no compartimento de digestão de tais unidades. Os dados produzidos em termos de concentrações de parâmetros físico-químicos devem ser organizados em planilhas, não somente para fins de manutenção da base de dados, mas para efetivamente subsidiar o controle operacional do sistema de tratamento do esgoto de forma contínua. No entanto, em muitos casos os dados de perfis de lodo (em termos de sólidos totais e voláteis) não são sistematicamente utilizados, e a sua correlação simultânea com dados de qualidade do efluente tende a ser ainda menos recorrente.

Massa de lodo e concentração efluente de sólidos sedimentáveis. A determinação da massa de lodo no compartimento de digestão é de fundamental importância para a previsão de uma rotina de descarte do lodo de excesso. A frequente determinação da concentração de sólidos sedimentáveis deve ser também considerada visando o monitoramento da qualidade do efluente do reator UASB, em função do controle da massa de lodo mantida no reator.

Frequências recomendadas para a caracterização da massa de lodo nos reatores UASB e concentrações efluentes de sólidos sedimentáveis. O plano de descarte de lodo de reatores UASB é baseado em per- 
fis de ST implementados a partir da amostragem de lodo ao longo do compartimento de digestão. Em princípio, a amostragem e subsequente elaboração de perfis de lodo deveriam ser efetuadas com base no crescimento efetivo (ou operacional) do lodo no interior dos reatores UASB. Neste caso, os perfis de lodo e a quantificação do lodo de excesso (lodo a ser descartado) seriam executados no momento em que a massa estimada de lodo no compartimento de digestão excedesse ligeiramente a massa de lodo recomendada para o período operacional, em função da carga de matéria orgânica aduzida ao sistema com o esgoto bruto. Em última análise, adotando-se tal estratégia garantir-se-á a compatibilidade entre o dimensionamento das unidades de desaguamento e a produção de lodo estimada em projeto $\left(\mathrm{Y}_{\text {lodo }}\right)$. A estimativa de volumes de lodo de desaguamento é apresentada na Parte 3 desta Coletânea de NTs (LOBATO et al. 2018).

Recomenda-se que a estrutura laboratorial e a respectiva equipe operacional da ETE sejam dimensionadas de forma a prover condições de implementação de perfis de ST associados a cada reator UASB: i) a cada 15 dias, no caso de reatores UASB sem recebimento de lodo aeróbio da unidade de pós-tratamento; e ii) um perfil por semana por reator, no caso de ETEs com reatores UASB recebendo lodo aeróbio proveniente dos decantadores secundários. Preferencialmente, as tomadas de amostras de lodo ao longo da altura do compartimento de digestão, para a determinação dos perfis de ST, devem ser feitas fora dos horários dos picos de vazão afluente aos reatores ( $p$. ex.: meio da manhã ou meio da tarde).

Evidentemente, tanto as unidades de desaguamento do lodo, bem como a equipe de operação, devem ser definidas visando garantir a execução das demandas baseadas nos resultados laboratoriais para o gerenciamento da fase sólida. Para o acompanhamento da qualidade do efluente recomenda-se que as concentrações de sólidos sedimentáveis sejam realizadas pelo menos duas vezes por semana, por reator, considerando preferencialmente amostragens compostas. Os dados considerados para a verificação da qualidade do efluente devem ser aqueles mais recentemente determinados, em relação ao último perfil de concentrações de ST fornecido.

\section{(ii) Controle operacional do lodo retido em decantadores secundários de FBPs e LA e critérios para o envio do lodo aos reatores UASB}

A remoção do lodo excedente nos reatores UASB em quantidade inferior à produção efetiva é causa potencial que contribui para a retenção de lodo de baixa sedimentabilidade nos reatores UASB. Adicionalmente, critérios inadequados para o envio do lodo de decantadores secundários para os reatores UASB podem contribuir para a elevação da carga de sólidos encaminhada a esses reatores e deterioração da qualidade do efluente anaeróbio. Neste sentido, além da compatibilização de estimativas de produção efetiva de lodo com o dimensionamento da etapa de desaguamento do lodo, as recomendações para a melhoria da qualidade do efluente em sistemas que adotam o envio do lodo aeróbio para os reatores UASB são:

\section{Preservação do lodo de melhor qualidade no} fundo dos reatores UASB. Conforme discutido em detalhes na Parte 3 desta Coletânea de NTs (LOBATO et al. 2018), o protocolo de descarte de lodo dos reatores UASB deve propiciar a preservação de parcela significativa do lodo de fundo (mais concentrado), de modo que este possa atuar como um "filtro" que auxilie na retenção e hidrólise dos sólidos suspensos contidos no lodo aeróbio enviado a partir dos decantadores secundários da unidade de pós-tratamento.

\section{Manutenção de baixas concentrações de lodo} na parte superior do compartimento de digestão dos reatores UASB. Conforme discutido anteriormente e também na Parte 3 desta Coletânea 
de NTs (LOBATO et al. 2018), deve-se garantir que o reator não esteja com excesso (passivo) de lodo em seu interior. A forma mais simples de se atestar que não existe excesso de lodo no reator é por meio da verificação sistemática do teor de ST no ponto mais elevado do compartimento de digestão (imediatamente antes do defletor de gases). A concentração de lodo nesse ponto deve ficar sempre abaixo de $0,5 \% \mathrm{ST}$.

\section{Manutenção de baixas concentrações de lodo} nos decantadores secundários. A compatibilização do crescimento efetivo de lodo nos reatores UASB com o dimensionamento do sistema de desaguamento tende a reduzir a demanda sobre a etapa de decantação secundária, em virtude de menores concentrações de SST no efluente anaeróbio e pós-tratamento por FBP ou LA. Por consequência, a carga de lodo aeróbio encaminhada aos reatores UASB tende a ser menor, assim como as concentrações de lodo nos decantadores secundários tendem a ser mais baixas. Recomenda-se que a concentração de lodo na etapa de decantação secundária não ultrapasse 1,0 \% ST.

Duas possíveis alternativas para sanar a problemática de criação de passivo de lodo nos DS na ETE seriam: i) incrementar o descarte de lodo dos reatores UASB de modo a não se ultrapassar a massa máxima nem a concentração recomendada de lodo na parte superior do compartimento de digestão; e ii) remover o passivo de lodo dos DS sem considerar o envio para os reatores UASB (p.ex.: por meio de caminhões limpa-fossa).

\section{Estabelecimento do período e vazão de en- vio do lodo aeróbio para os reatores UASB. Re-} comenda-se que o envio do lodo proveniente de decantadores secundários seja realizado no período do dia em que se observa a menor vazão de esgoto bruto afluente à ETE (via de regra, o período de menor vazão aduzida ocorre durante a madrugada). Neste caso, as bombas de envio de lodo devem ser operacionalizadas para o encami- nhamento do lodo aeróbio ao longo de todo o período de menor vazão. Esta estratégia operacional visa manter o lodo de menor sedimentabilidade em regiões do compartimento de digestão onde se observa maior concentração de ST.

\subsection{Verificação do nivelamento dos vertedores e da existência de fugas de gases do STF}

A necessidade de nivelamento de vertedores pode ser definida a partir da observação de vazões irregulares ao longo do alinhamento de saída do efluente anaeróbio. Além do nivelamento de canaletas, a verificação de velocidades ascensionais e o tempo de detenção do líquido no compartimento de digestão e decantação, respectivamente, podem ser importantes aspectos a serem verificados, no sentido de se evitar o acúmulo de escuma. A justificativa para tal verificação reside no fato de que a má distribuição do líquido entre os reatores UASB também pode ser uma causa para o acúmulo de escuma na superfície do compartimento de digestão, conforme anteriormente mencionado.

\subsection{Redução dos picos de vazões afluentes aos reatores}

Conforme apontado na Parte 1 desta Coletânea de NTs (CHERNICHARO et al., 2018b), os possíveis aprimoramentos visando reduzir os impactos decorrentes dos elevados picos de vazões de esgoto aduzidas aos reatores UASB estão relacionados a: i) utilização de bombas com variadores de velocidade (inversores de frequência) ou o mínimo de três bombas, sendo uma para rodízio e reserva; e ii) implantação de extravasores que efetivamente protejam as unidades subsequentes do tratamento quanto a sobrecargas hidráulicas. Um maior detalhamento das ações que podem ser empreendidas é discutido na Parte 2 desta Coletânea de NTs (BRESSANI-RIBEIRO et al., 2018). 


\section{ORIGEM E PROBLEMAS RELACIONADOS AO ATENDIMENTO A PADRÕES DE LANÇAMENTO}

As legislações brasileiras que versam sobre os padrões de lançamento do esgoto tratado em corpos de água têm definido principalmente limites para concentrações de matéria orgânica. Os limites de lançamento referentes a concentrações de nitrogênio total, fósforo e surfactantes tendem a ser observados em casos específicos, como para o lançamento de efluentes em ambientes lênticos, ou ainda no contexto de legislações mais restritivas. Via de regra, tais parâmetros são contextualizados para padrões de qualidade de corpos receptores, para o que são consideravelmente restritivas. 0 tratamento anaeróbio, apesar de exercer um importante papel na redução de cargas orgânicas provenientes do esgoto sanitário, usualmente apresenta limitações para o atendimento aos requisitos de lançamento em corpos receptores. A seguir são apresentados alguns aspectos que dificultam o atendimento a padrões de qualidade considerando somente o uso da etapa anaeróbia na redução de cargas orgânicas e remoção de nutrientes e surfactantes.

\subsection{Remoção de matéria orgânica}

Os reatores UASB são eficientes na redução da carga orgânica biodegradável do esgoto bruto, razão pela qual os padrões de qualidade para o corpo de água são potencialmente atendidos em condições em que se tem elevadas razões de diluição no corpo receptor. Contudo, no caso de inadequações de projeto, construção e operação, a elevada perda de sólidos com o efluente anaeróbio é um fator que tende a prejudicar o atendimento a padrões de lançamento e o desempenho da etapa de pós-tratamento. Cabe ainda ressaltar que a baixa concentração de oxigênio dissolvido em efluentes de reatores UASB também pode ser uma limitação, em termos do impacto do lançamento do efluente em um corpo receptor.

\subsection{Remoção de compostos nitrogenados}

Da mesma forma que para o atendimento a padrões de qualidade associados à matéria orgânica, o atendimento a padrões de qualidade para concentrações de compostos nitrogenados apenas com reatores UASB tende a ser uma opção mais restrita. Considerando as condições operacionais impostas para a operação da etapa anaeróbia, a assimilação e a amonificação são os processos metabólicos de maior relevância associados ao ciclo do nitrogênio. Neste caso, as transformações de compostos nitrogenados praticamente não resultam em remoção de $\mathrm{N}$-amoniacal ou nitrogênio, sendo este um aspecto inerente ao processo de digestão anaeróbia, e não propriamente um problema originado em definições de projeto, construção ou operação.

\subsection{Remoção de surfactantes}

A composição de diversos produtos de limpeza e higiene pessoal inclui substâncias tensoativas ou surfactantes, com a finalidade de reduzir a tensão superficial da água. Tais compostos são precursores de espuma em ETEs ou em cursos d'água nos quais ocorre o lançamento de efluentes. A formação de espuma pode ocorrer a partir da ligação destes compostos com a superfície de bolhas de ar devido a eventuais turbilhonamentos presentes ao longo do processo de tratamento ou ao gradiente hidráulico existente entre o ponto de lançamento do efluente e o curso d'água. Embora o alquibenzeno linear sulfonado (LAS), surfactante mais utilizado em nível mundial, seja biodegradável, sua degradação sob condições anaeróbias é limitada, da ordem de 35\% (Duarte et al., 2008).

\subsection{Remoção de fósforo}

A remoção de fósforo $(P)$ em reatores anaeróbios é bastante restrita, sendo também esta uma limitação inerente ao processo de digestão anaeróbia e não propriamente um problema originado em de- 
finições de projeto, construção ou operação. Apenas em condições de elevadas razões de diluição no corpo receptor é que os padrões de qualidade podem ser atendidos. Ainda que a etapa de pós-tratamento seja uma opção para o atendimento a padrões de qualidade em relação a concentrações de fósforo (p.ex.: em sistemas de lodo ativado pós-reator UASB), a remoção biológica deste componente em etapa de pós-tratamento encontra dois desafios: i) relação P/DQO superior aos valores desejados para desempenhos elevados; e ii) liberação de fósforo sob condições anaeróbias, no caso de encaminhamento do lodo para adensamento e digestão no reator UASB. Maiores detalhes sobre a remoção biológica de fósforo são apresentados em Chernicharo et al. (2001) e von Sperling (2017). Cabe ressaltar que há poucos processos de pós-tratamento que conduzem a elevadas remoções de fósforo.

\subsection{Recebimento de efluentes não domésticos}

O recebimento de efluentes não domésticos (ENDs) em ETEs tratando esgoto doméstico tem sido uma realidade vigente no contexto brasileiro, principalmente em regiões onde a expansão industrial ocorre de forma mais eminente. A contribuição de efluentes advindos de aterros sanitários como lixiviados (chorume) também deve ser destacada, visto que, a depender da razão de diluição com o esgoto bruto, podem ocorrer problemas de toxicidade que impactariam a digestão anaeróbia. Adicionalmente, o recebimento de lodo de tanques sépticos pode induzir ao incremento do coeficiente de produção de lodo nos reatores UASB, o que tende a potencializar a perda de sólidos no efluente anaeróbio, caso o projeto não tenha contemplado o recebimento deste tipo de contribuição. Uma discussão mais aprofundada sobre a origem e problemas associados ao recebimento de lixiviado de aterro sanitário, de ENDs e de lodo de tanques sépticos em reatores UASB é apresentada na Parte 3 desta Coletânea de NTs (LOBATO et al., 2018).

\section{POSSIVEIS APRIMORAMENTOS}

\section{RELACIONADOS AO ATENDIMENTO A PADRÕES DE LANÇAMENTO}

A melhoria da qualidade do efluente anaeróbio por meio de pós-tratamento é um tema vasto. Há uma série de sistemas naturais e mecanizados que devem ser levados em consideração a depender dos objetivos do tratamento, bem como dos requisitos necessários para a implantação e operação (demanda de área, custos, logística de gerenciamento de subprodutos). Tal como caracterizado na introdução desta NT, o presente item aborda exclusivamente a utilização de filtros biológicos percoladores (FBP), por se tratarem da alternativa de pós-tratamento mais empregada nas ETEs brasileiras que utilizam reatores anaeróbios como primeiro estágio do tratamento (CHERNICHARO et al. 2018b).

\subsection{Remoção de matéria orgânica}

As experiências associadas à remoção complementar de matéria orgânica em FBPs pós-reatores UASB encontram-se bem estabelecidas. Logo, a adoção de FBPs de alta carga com leito de pedra (cargas orgânicas volumétricas aplicadas em torno de 0,50-1,00 kg-DBO.m ${ }^{-3} \cdot \mathrm{d}^{-1}$ ) permitem a obtenção de eficiências globais (UASB+FBP) de remoção de matéria orgânica usualmente acima de $85 \%$.

\subsection{Remoção de compostos nitrogenados}

Para os casos em que a remoção de nitrogênio total se faz necessária, os filtros biológicos percoladores preenchidos com leito de pedras pós-reatores UASB são pouco eficazes, considerando as condições e estratégias operacionais usualmente estabelecidas. Da mesma forma, FBPs de alta carga pós-reatores UASB proporcionam uma remoção de $\mathrm{N}$-amoniacal pouco satisfatória, em torno de $20 \%$. Para um aumento da atividade nitrificante nos FBPs (remoção de $\mathrm{N}$-amoniacal 
acima de 50\%) cargas orgânicas volumétricas aplicadas abaixo de 0,24 kg-DBO.m ${ }^{-3} \cdot \mathrm{d}^{-1}$ devem ser utilizadas no projeto das unidades. Nestes casos, a etapa de decantação secundária pode não ser necessária, considerando os padrões de lançamento menos restritivos via de regra praticados no contexto nacional. A partir de experiência de longo termo em escala plena, a utilização de material de enchimento baseado em espuma de poliuretano parece ser uma potencial alternativa para a remoção de $\mathrm{N}$-amoniacal e $\mathrm{N}$-total em FBPs pós-reatores UASB (ONODERA et al., 2016), todavia as experiências nacionais ainda são restritas a sistemas em escala de demonstração (BRESSANI-RIBEIRO et al., 2017).

Em contraponto à lógica de remoção de nutrientes da fase líquida, ressalta-se que a utilização de sistemas de pós-tratamento associados à aplicação no solo (p.ex.: fertirrigação e/ou recarga de aquíferos) e a utilização do efluente para fins menos nobres (p. ex.: supressão de poeira em áreas com acesso público restrito) pode reduzir a necessidade de remoção de nutrientes. A discussão detalhada de tais possibilidades técnicas foge ao escopo desta NT.

\subsection{Remoção de surfactantes}

Conforme abordado anteriormente, a degradação de surfactantes sob condições anaeróbias é limitada. Uma alternativa para se alcançar uma elevada degradação biológica de surfactantes presentes em efluentes de reatores UASB é a adoção de uma tecnologia de pós-tratamento aeróbia, uma vez que eficiências de degradação de LAS superiores a $99 \%$ são reportadas para processos aeróbios (BRUNNER et al., 1988). Complementarmente, uma alternativa para minimizar a formação de espuma em cursos d'água está associada ao lançamento submerso do efluente, objetivando reduzir condições turbulentas precursoras da formação de espuma.

\subsection{Remoção de fósforo}

Dentre os processos atualmente passíveis de serem aplicados ao pós-tratamento de efluentes de reatores UASB visando à remoção de fósforo, destacam-se os físico-químicos. Embora a remoção de fósforo em ETEs possa ocorrer por via biológica, nos reatores UASB praticamente toda a matéria orgânica rapidamente biodegradável é consumida. Essa elevada remoção de matéria orgânica não propicia o estabelecimento de condições adequadas ao desenvolvimento de microrganismos acumuladores de fósforo na etapa de pós-tratamento por lodo ativado (von SPERLING, 2017).

No que se refere à remoção físico-química de fósforo, os produtos comumente utilizados são os sais de alumínio, ferro e cálcio. Adicionalmente, polímeros também têm sido utilizados a fim de auxiliar a floculação. A remoção de fósforo efetivamente ocorre a partir da formação dos fosfatos de metais e de cálcio, os quais podem ser posteriormente removidos por sedimentação, flotação e, eventualmente, filtração, a depender da concentração efluente desejada.

Cabe ressaltar que a dosagem de produtos químicos usualmente acarreta um aumento expressivo na produção de lodo no sistema, o que deve ser estritamente considerado no momento de concepção da tecnologia de tratamento de esgoto a ser empregada, quando a remoção de fósforo é um objetivo. Todavia, os processos físico-químicos são indispensáveis caso a remoção de fósforo seja almejada pós-reatores UASB. Neste caso, tal etapa poderia ocorrer entre o reator biológico (p.ex.: FBP ou lodo ativado) e o decantador secundário.

\section{ORIGEM E PROBLEMAS RELACIONADOS AO PÓS-TRATAMENTO POR FBP}

Distribuição do efluente. Nos casos em que o efluente não seja uniformemente distribuído sobre o meio suporte, o molhamento efetivo e o aprovei- 
tamento da área superficial tendem a ser reduzidos. Consequentemente, parte do FBP será alimentado com maiores cargas hidráulicas, podendo, inclusive, ser a causa de frequentes empoçamentos pela elevação da carga de sólidos afluente. A depender da relevância em termos da má distribuição do efluente, é possível que o desempenho do sistema seja menor do que o esperado, fundamentalmente em virtude da redução da área superficial utiliza- da para a colonização microbiana e formação do biofilme. Na Figura 5 (a-b) é apresentado um um exemplo de má distribuição do efluente no topo de um FBP preenchido com leito de pedras e a ocorrência de empoçamentos pela colmatação na superfície do leito. Tal colmatação pode ser ainda acelerada devido ao preenchimento de FBPs com pedras britadas de granulometria inadequada, tal como discutido adiante.
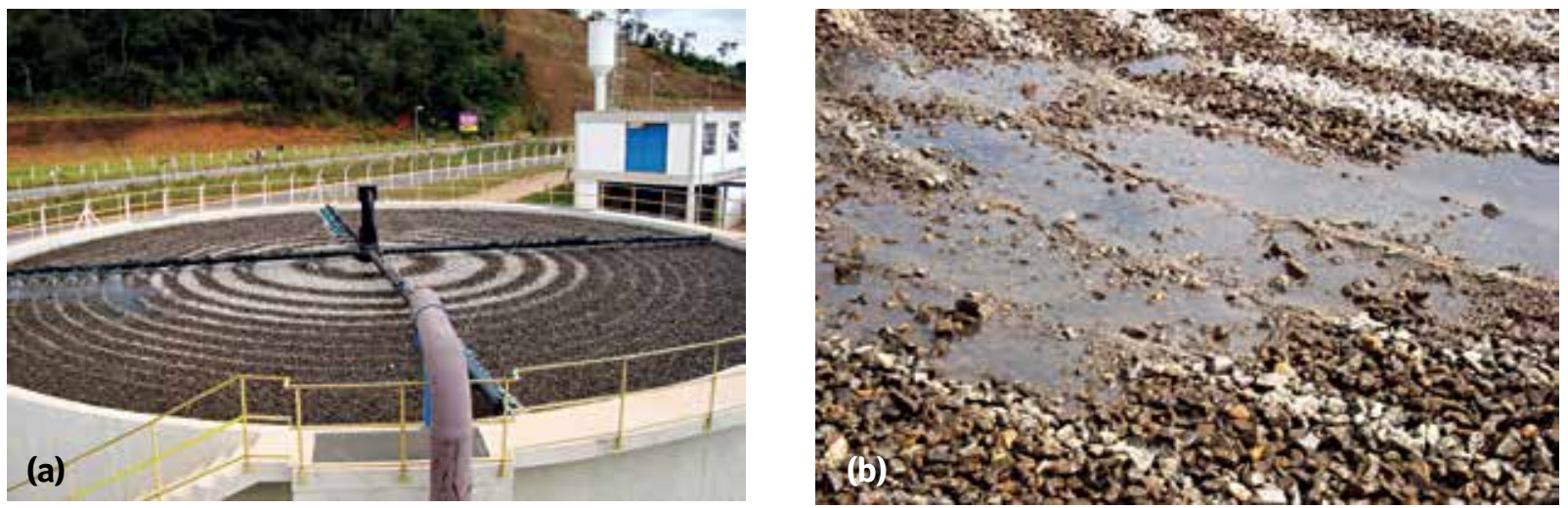

Figura 5 - a) Má distribuição do efluente no topo de filtro biológico percolador pós-reatores UASB; b) colmatação do leito de pedras por elevação da carga de sólidos.

Cabe ainda ressaltar que a obstrução de orifícios e/ou travamento dos braços distribuidores podem também ser uma eventual causa da má distribuição do efluente no topo do FBP (Figura 6). A origem de entupimentos dos orifícios é frequentemente associada à elevada perda de sólidos no reator UASB, em virtude de falhas no gerenciamento do lodo. A entrada de detritos em excesso nos reatores UASB por deficiências nas unidades do tratamento preliminar pode também ser uma causa potencial para tais obstruções. Já o travamento dos braços distribuidores associa-se usualmente à qualidade do equipamento e a deficiências de manutenção. Adicionalmente, em momentos de baixa vazão afluente, pode haver o comprometimento do número de passadas do braço previstas em projeto, especialmente para sistemas que não empregam motores periféricos de acionamento (situação usual no país).

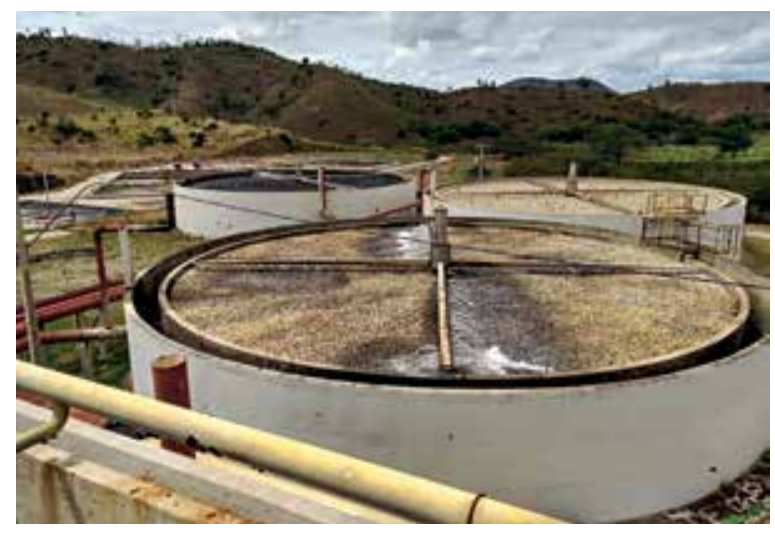

Figura 6 - Distribuição desigual de esgoto em FBP decorrente de obstrução de orifícios e/ou travamento dos braços rotatórios.

Granulometria de leitos de pedra. No contexto brasileiro os leitos de pedra são frequentemente utilizados como meio suporte. Neste caso, a colmatação devido à perda excessiva de sólidos com o efluente de reatores UASB torna-se mais prová- 
vel, em virtude do baixo índice de vazios do meio suporte. A possibilidade de tal observação é aumentada quando a granulometria recomendada (britas $\mathrm{n}^{\circ} 4$ e 5: granulometria entre $50-100 \mathrm{~mm}$ de diâmetro) não é respeitada. Em alguns casos, experiências práticas apontam o recebimento de volumes de pedra britada em considerável desacordo com as recomendações de projeto, incluindo a presença de materiais finos, como mostrado na Figura 7 (a-b).

Esta constatação reside no fato de que as pedras britadas $n^{\text {os }} 4$ e 5 não são frequentemente utiliza- das na construção civil. Assim, o controle de produção e qualidade do referido material tende a ser menos consistente. Para o fornecimento de grandes volumes de material, como é o caso observado para o preenchimento de filtros biológicos percoladores em escala plena, as limitações em termos de fornecimento parecem ser ainda mais relevantes. Portanto, as limitações para o controle de qualidade em relação a leitos de pedra como material de enchimento e um menor rigor operacional para o controle do lodo em reatores UASB são elementos potenciais para o mau funcionamento de FBPs como etapa de pós-tratamento.
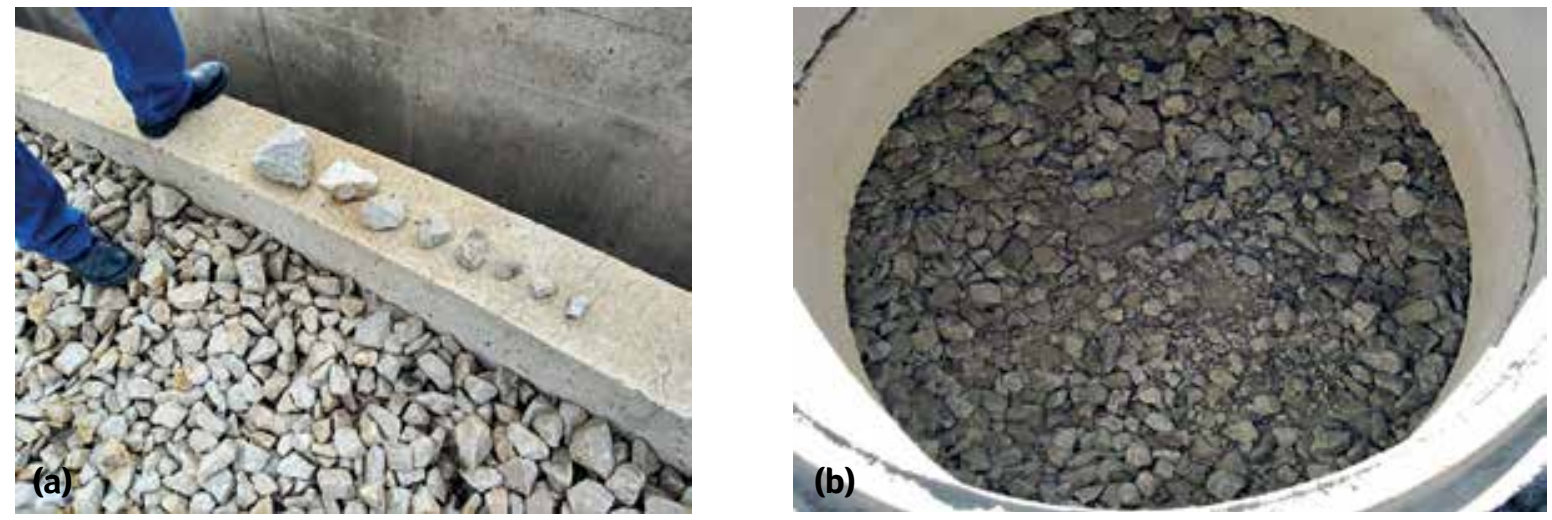

Figura 7 - (a-b) Fornecimento de pedra britada em desacordo com especificações de projeto, incluindo a presença de materiais finos na composição do material de enchimento.

A colmatação do meio suporte provoca a criação de caminhos preferenciais para a passagem do ar e líquido, impondo dificuldades em relação ao atendimento de requisitos de oxigênio para as reações aeróbias na etapa de pós-tratamento (TCHOBANOUGLOUS et al., 2003). Adicionalmente, tem sido observada a redução da atividade nitrificante com o aumento de concentrações de materiais particulados no líquido, tanto em estudos laboratoriais (FIGUEROA e SILVERSTEIN, 1992) como a partir de dados operacionais referentes a sistemas em escala de demonstração (ALMEIDA, 2011). Nestes casos, a maior presença de matéria orgânica, a menor disponibilidade de oxigênio e a maior resistência à transferência de massa explicariam a redução da atividade nitrificante em sistemas com biofilme.

Escolha do meio suporte. $O$ desempenho de um FBP pós-reator UASB tende a estar associado ao meio suporte utilizado para o preenchimento do volume reacional. Em princípio, espera-se que o uso de meios suportes com maior área superficial específica (p.ex.: meios plásticos) resultem em maior desempenho ao FBP, em termos de remoção de matéria orgânica e $\mathrm{N}$-amoniacal. No entanto, a falta de uma acurada observação de projeto em relação ao molhamento efetivo do meio suporte, bem como em relação às cargas orgânicas aplicadas, 
podem vir a serem causas para um menor desempenho de FBPs preenchidos com meios suportes de maior área superficial específica.

Considerando uma condição específica de cargas orgânicas aplicadas $\left(0,25-0,45 \mathrm{~kg}-\mathrm{DBO} \cdot \mathrm{m}^{3} \cdot \mathrm{d}^{-1}\right) \mathrm{e}$ taxas de aplicação superficial $\left(10-20 \mathrm{~m}^{3} \cdot \mathrm{m}^{-2} \cdot \mathrm{d}^{-1}\right)$ em um estudo objetivando a escolha de meio suporte para o preenchimento de FBPs, Almeida (2007) observou que o uso de meios plásticos (área superficial específica entre 80 e $200 \mathrm{~m}^{3} \cdot \mathrm{m}^{-2}$ ) não trouxe nenhum benefício significativo para a melhoria da qualidade do efluente, em comparação com o leito de pedras para remoção de matéria orgânica e $\mathrm{N}$-amoniacal. As baixas cargas orgânicas aplicadas certamente exerceram influência no desempenho dos FBPs preenchidos com meios suportes de maior área superficial específica. Adicionalmente, a recirculação contínua do efluente não foi considerada, sendo este um aspecto relevante para o aumento da eficiência de molhamento de meios suporte, a depender das condições operacionais impostas.

\section{POSSIVEIS APRIMORAMENTOS \\ RELACIONADOS AO PÓS-TRATAMENTO POR FBP}

\subsection{Distribuição do afluente em FBPs}

Nos casos excepcionais em que a distribuição do efluente seja realizada de forma irregular sobre a superfície do FBP é importante que haja uma revisão do equipamento utilizado, visando o reposicionamento e/ou a revisão do diâmetro de orifícios. 0 objetivo de tais redimensionamentos é tornar uniforme a distribuição do efluente no topo dos FBPs e, por consequência, promover melhorias em termos do molhamento efetivo do meio suporte (Figura 8 (a-b)). Para sistemas rotativos de distribuição, recomenda-se que tais redimensionamentos considerem o número de passadas por minuto sobre o meio suporte, conforme definido em projeto. A utilização de sistemas motorizados (moto-redutor fixado a um dos braços distribuidores e apoiado na parede externa do FBP) visando manter a rotação dos braços pode ser uma alternativa efetiva nos casos em que o número de passadas definido em projeto seja incompatível com a energia hidráulica proveniente do efluente anaeróbio.
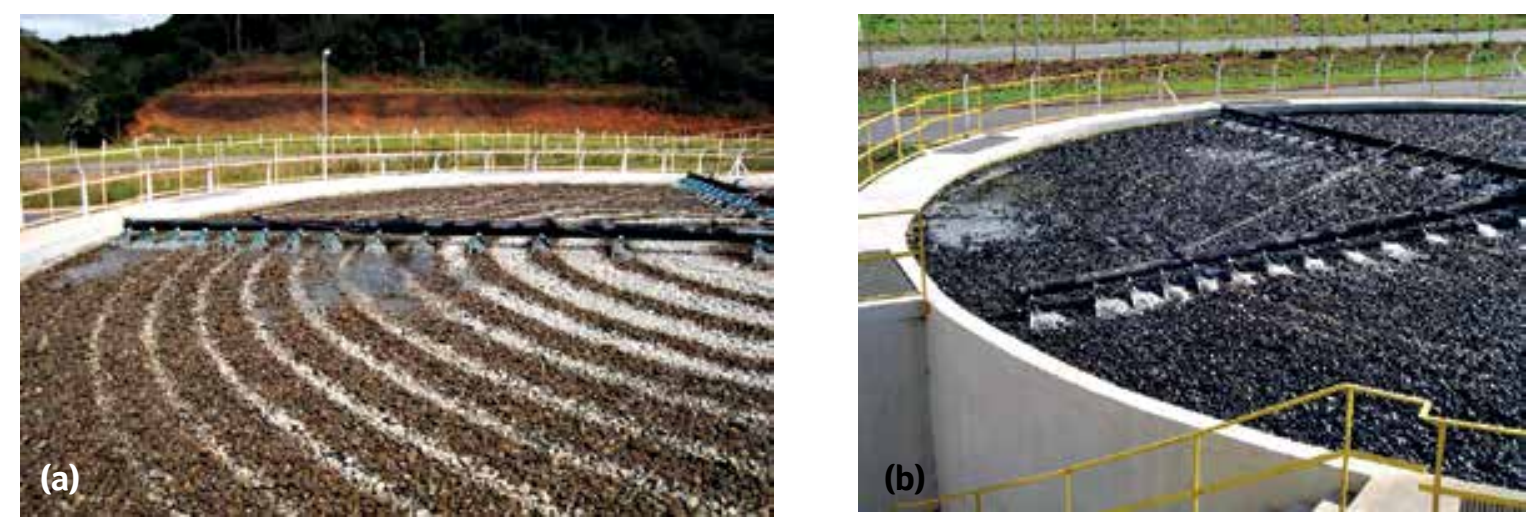

Figura 8 - (a-b) Revisão do posicionamento de orifícios nos braços de um distribuidor rotativo. 


\subsection{Meio suporte para FBPs}

Caso as definições de projeto indiquem o uso de leito de pedras para o preenchimento dos FBPs pós-reatores UASB, deve-se atentar para o adequado atendimento às especificações e à fiscalização durante a aquisição do material e preenchimento dos filtros. As recomendações a seguir devem ser consideradas:

Especificação de projeto. Deve constar do projeto que o leito de pedras de granito, gnaisse ou basalto deverá ser composto de pelo menos $95 \%$ do material retido em peneira com diâmetro entre 50-100 mm (britas n 4 e 5), não havendo a possibilidade de admissão de material com a presença de materiais finos em frações visualmente excessivas. Esta verificação deverá ser efetuada antes do envio do material ao canteiro, junto ao fornecedor. Pedras "chatas" mais alongadas e de baixa espessura devem ser evitadas em quantidades representativas.

Recebimento do material em canteiro de obra. Rigor da fiscalização no recebimento do material. Para tal, recomenda-se que uma verificação granulométrica em campo deva ser realizada por meio de amostragens, no sentido de evitar a necessidade de eventuais substituições no meio de enchimento, uma prática potencialmente inviável. As amostragens deverão ser executadas para cada descarga de material nos FBPs. Adicionalmente, o canteiro de obra deverá dispor de área apropriada para a estocagem do material, de preferência limpa e pavimentada, de modo a evitar que o material se misture com materiais impróprios presentes no local (p. ex.: terra), mais especificamente quando do uso de pás carregadeiras para carga do material no interior dos FBPs.

Colocação e espalhamento do material no interior do FBP. Definição da técnica mais apropriada para colocação e espalhamento do material no interior do FBP, tendo em vista que a forma usual, por meio de pás carregadeiras, tem ocasionado vários problemas (p. ex.: quebra das pedras e carregamento de solo juntamente com as pedras). Também a forma de espalhamento do material deve ser definida com rigor, a fim de evitar o uso de máquinas pesadas que possam causar a quebra das pedras e a geração de finos.

Escolha do meio suporte. Como mencionado anteriormente, os FBPs pós-reatores UASB em operação no Brasil são usualmente preenchidos com leito de pedras, quando projetados para a remoção de matéria orgânica. No entanto, (i) as dificuldades de atendimento às especificações granulométricas para sistemas de grande porte, (ii) a necessidade de atendimento a padrões de lançamento em termos de $\mathrm{N}$-amoniacal, bem como (iii) o maior dispêndio de recursos com estruturas de concreto armado, podem ser fatores limitantes em relação à aplicabilidade de leito de pedras como material de enchimento. Nesses casos, os volumes reacionais tendem a ser bastante elevados, e a redução do tamanho e robustez dos FBPs passam a ser aspectos de maior relevância para a escolha do meio suporte, perante os menores custos de aquisição da pedra britada. Isto porque o peso específico de meios plásticos (30-60 kg. $\left.\mathrm{m}^{-3}\right)$ é significativamente menor em comparação ao leito de pedras $\left(1.350 \mathrm{~kg} \cdot \mathrm{m}^{-3}\right)$.

Em última análise, o uso de meio suporte com maior área superficial específica pode ser uma potencial alternativa para os casos em que:

- a remoção de matéria orgânica não seja o único objetivo da etapa de pós-tratamento. Nestes casos, o custo de aquisição de um meio suporte de maior área superficial e menor peso específico pode ser compensado pela redução do tamanho do volume reacional;

- o maior controle de qualidade em termos do material de enchimento fornecido seja um aspecto de interesse. $O$ controle na produção de meios plásticos tende a ser melhor do que o que se observa para a produção de pedra britada com granulometria entre $50-100 \mathrm{~mm}$. 


\section{CONSIDERACÕES FINAIS}

Verificadas as recomendações para o projeto, construção e operações de reatores UASB, a qualidade do efluente anaeróbio requer o gerenciamento adequado do lodo na ETE, um aspecto que merece ainda mais atenção com o envio do lodo aeróbio proveniente da etapa de pós-tratamento aos reatores UASB, para adensamento e digestão. Cabe ressaltar que, independentemente da tecnologia de pós-tratamento utilizada, no caso do uso de decantadores secundários, a sistematização da estratégia operacional associada ao envio do lodo para os reatores UASB tende a seguir as mesmas recomendações observadas nesta Nota Técnica para o uso de FBPs pós-reatores UASB. Adicionalmente, uma atenção especial deve ser dada a aspectos que venham a produzir um efeito deletério para a qualidade do efluente anaeróbio, tal como o acúmulo de escuma em compartimentos de decantação e separadores trifásicos, bem como as sobrecargas hidráulicas que eventualmente possam vir a elevar as concentrações de lodo no compartimento de decantação dos reatores UASB.

Considerando tecnologias simplificadas para o pós-tratamento de efluentes de reatores UASB, o uso de FBPs preenchidos com meios plásticos ou baseados em espuma de poliuretano tende a ser uma potencial alternativa para a melhoria da qualidade do efluente final e atendimento a requisitos de lançamento em corpos receptores. Neste caso, a aplicação de tais meios suportes pode ser uma possibilidade em vista dos problemas observados a partir do preenchimento de volumes reacionais com pedra britada.

\section{AGRADECIMENTOS}

Os autores agradecem o apoio recebido do Conselho Nacional de Desenvolvimento Científico e Tecnológico - CNPq, da Coordenação de Aperfeiçoamento de Pessoal de Nível Superior - CAPES, da Fundação de Amparo à Pesquisa do Estado de
Minas Gerais - FAPEMIG e do Instituto Nacional de Ciência e Tecnologia em Estações Sustentáveis de Tratamento de Esgoto - INCT ETEs Sustentáveis.

Este trabalho faz parte da série de publicações do INCT ETEs Sustentáveis.

\section{REFERÊNCIAS}

ALEM SOBRINHO P., JORDÃO E.P. Pós-tratamento de efluentes de reatores anaeróbios - uma análise crítica. Cap. 9. In: Chernicharo C.A.L (coordenador). Pós-tratamento de efluentes de reatores anaeróbios. FINEP/PROSAB, Rio de Janeiro, Brasil, 544 p, 2001.

ALMEIDA, P.G.S. Remoção de matéria orgânica e nitrogênio em filtros biológicos percoladores aplicados ao pós-tratamento de efluentes de reatores UASB. 2011.196p. Tese (Doutorado em Saneamento, Meio Ambiente e Recursos Hídricos) - Escola de Engenharia, Universidade Federal de Minas Gerais, Belo Horizonte, 2011.

BRESSANI-RIBEIRO, T., BRANDT, E.M.F., ALMEIDA, P.G.S., FLÓREZ, C.A.D. CHERNICHARO, C.A.L. Technological improvements in compact UASB/SBTF systems for decentralized sewage treatment in developing countries. Desalination and Water Treatment. p. 01-09, 2017.

BRESSANI-RIBEIRO, T, LOBATO, L.C.S, MELO, V.R., PEGORINI, E., NONATO, S., CHERNICHARO, C.A.L. Contribuição para o aprimoramento de projeto, construção e operação de reatores UASB aplicados ao tratamento de esgoto sanitário - Parte 2: Tratamento Preliminar. Revista DAE - edição especial, v. 66, n. 214, p. 17-29, 2018.

BRUNNER P.H, CAPRI S., MARCOMINI A., GIGER W. Occurrence and behaviour of linear alkylbenzene sulphonates, nonylphenol, nonylphenol mono-and nonylphenol diethoxylates in sewage and sewage sludge treatment. Water Research, v. 22, n. 12, p., 1465-1472, 1988.

CHERNICHARO, C.A.L (coordenador). Pós-tratamento de efluentes de reatores anaeróbios. FINEP/PROSAB, Rio de Janeiro, Brasil, 544 p, 2001.

CHERNICHARO, C.A.L., VON SPERLING, M., MONTEIRO, T.A.S. Evaluation of post-treatment alternatives for effluents from the UASB reactors of Onça Sewage Treatment Plant (Belo Horizonte-Brazil). In: VIII Taller y Simposio Latino Americano sobre Digestion Anaerobia, Punta del Este, Uruguay: IWA, 2005.

CHERNICHARO, C.A.L., LOBATO, L. C. S., PAVIA JÚNIOR, C. A., BARBOSA, C. A., ALMEIDA, P. G. S., GONÇALVES, T. C. F., VAZ, E., SOUZA, J. R., SILVA, L. R., JUDICE, M. A. M., MORAES, O. J. Secondary sludge return for thickening and digestion in UASB reactors: case study of Onça STP - Brazil. In: XI Taller y Simposio Latino Americano sobre Digestion Anaerobia, La Havana, Cuba - IWA, 2013. 
CHERNICHARO, C.A.L., BRESSANI-RIBEIRO, T., GARCIA, G.B., LERMONTOV, A., PEREIRA, C.B., PLATZER, C.J., POSSETTI, G.R.C., LEITES, M.A.L., ROSSETO, R. Panorama do tratamento de esgoto sanitário nas regiões Sul, Sudeste e Centro-Oeste do Brasil: tecnologias mais empregadas. Revista DAE, vol. 66 (2013), p. 5-19, 2018 a.

CHERNICHARO, C.A.L, BRESSANI-RIBEIRO, T, PEGORINI, E., POSSETTI, G.R.C., MIKI, M. K., NONATO, S. Contribuição para o aprimoramento de projeto, construção e operação de reatores UASB aplicados ao tratamento de esgoto sanitário - Parte 1: Tópicos de Interesse. Revista DAE - edição especial, v. 66, n. 214, p. 5-16, 2018b.

DUARTE, I. C. S., OLIVEIRA, L. L., SAAVEDRA, N. K. D., FANTINATTI-GARBOGGINI, F., OLIVEIRA, V. M., VARESCHE, M. B. A., Evaluation of the microbial diversity in a horizontal-flow anaerobic immobilized biomass reactor treating linear alkylbenzene sulfonate. Biodegradation, v. 19, n. 3, p. 375-385, 2008.

FIGUEROA, L., SILVERSTEIN, J. The effect of particulate organic matter on biofilm nitrification. Water Environment Research. v. 64, n. 5, p. 728-733, 1992.

GONÇALVES, T.C.F. Avaliação da prática de retorno de lodo secundário sobre o desempenho de reatores UASB em escala plena: estudo de caso da ETE Laboreaux, Itabira/MG. Dissertação (Mestrado em Saneamento, Meio Ambiente e Recursos Hídricos) Escola de Engenharia, Universidade Federal de Minas Gerais, Belo Horizonte, 2015.

LOBATO, L.C.S., BRESSANI-RIBEIRO, T.B., SILVA, B.S., DIAS-FLÓREZ C.A, NEVES, P.N.P., CHERNICHARO, C.A.L. Contribuição para o aprimoramento de projeto, construção e operação de reatores UASB aplicados ao tratamento de esgoto sanitário - Parte 3: Gerenciamento do lodo e escuma. Revista DAE - edição especial, v. 66, n. 214, p. 30-55, 2018.
ONODERA, T.; OKUBO, T; UEMURA, S.; YAMAGUCHI, T.; OHASHI, A.; HARADA, H. Long-term performance evaluation of down-flow hanging sponge reactor regarding nitrification in a full-scale experiment in India. Bioresource Technology. 204. p. 177-184, 2016.

POSSETTI, G. R. C., RIETOW, J.C., COSTA, F.J.O.G., WAGNER, L.G., LOBATO, L. C. S., BRESSANI-RIBEIRO, MELO, D. F, REIS, J.A, CHERNICHARO, C. A. L. Contribuição para o aprimoramento de projeto, construção e operação de reatores UASB aplicados ao tratamento de esgoto sanitário - Parte 5: Biogás e emissões fugitivas de metano. Revista DAE - edição especial, v. 66, n. 214, p. 73-89, 2018.

SILVA, B.S. Desempenho de Reator UASB em escala plena no tratamento de esgoto sanitário e lodo ativado em excesso do pós-tratamento. Dissertação (Mestrado em Engenharia Hidráulica) - Escola Politécnica da USP, Universidade de São Paulo, São Paulo, 2018.

TANDUKAR, M., OHASHI, A., HARADA, H. Performance comparison of a pilot-scale UASB and DHS system and activated sludge process for the treatment of municipal wastewater. Water Research. v. 41, n. 12, p. 2697-2705, 2007.

TCHOBANOGLOUS, G., BURTON, F., STENSEL, H. Wastewater engineering: treatment, and reuse. New York: McGraw-Hill, 4th Ed., 2003, 1819 p.

VON SPERLING. M. Lodos Ativados. $2^{\mathrm{a}}$ ed. Belo Horizonte: Departamento de Engenharia Sanitária e Ambiental. Universidade Federal de Minas Gerais, 2002. 428 p. (Princípios do tratamento biológico de águas residuárias, v4).

VON SPERLING. M. Introdução à qualidade das águas e ao tratamento de esgotos. $4^{\mathrm{a}}$ ed. Belo Horizonte: Departamento de Engenharia Sanitária e Ambiental. Universidade Federal de Minas Gerais, 2017. 452 p. (Princípios do tratamento biológico de águas residuárias, v1). 


\section{Óleoeágua não se misturam}

\section{A solução é reciclar}

Não jogue óleo na rede de esgoto ou no solo, nem em ralos e vasos sanitários.

Cada litro de óleo de fritura pode poluir até 25 mil litros de água, se descartado de forma errada.

Uma solução mais responsável e ecológica é reciclar para fabricar sabão e biocombustivel.

Ao se desfazer do óleo usado, utilize garrafas PET usadas, embalagens de amaciantes ou de sucos.

Leve seu óleo usado até um dos pontos de coleta para que seja descartado de forma correta.

Conheça o PROL - Programa de Reciclagem de Óleo de Fritura no site www.sabesp.com.br

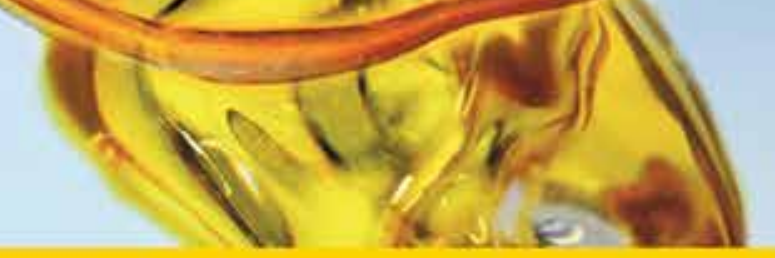

